\title{
MENINGKATKAN KESADARAN ORANG TUA DAN ANAK MELALUI PENYULUHAN MENGENAI PENERAPAN PROTOKOLER KESEHATAN DI MASA PANDEMI COVID - 19 DI PAUD NUR QOLBU LINGKUNGAN PERUMNAS CIRACAS KELURAHAN CIRACAS KECAMATAN SERANG KOTA SERANG PROVINSI BANTEN
}

\author{
Marthalena $^{1 *}$, Siska Mardiana ${ }^{2}$,Rethorika Berthanila ${ }^{3}$ \\ Program Studi Ilmu Komunikasi, Universitas Serang Raya ${ }^{12}$ \\ Program Studi Administrasi Publik, Universitas Serang Raya ${ }^{3}$ \\ Corresponding Author*: marthalena.marthalena@gmail.com
}

\begin{abstract}
Maintaining cleanliness and environmental health from an early age is one of the most important factors that must be considered in everyday life, especially now that our country and even the world is experiencing a covid-19 pandemic, therefore personal and environmental health needs to be considered, especially for children. children and elderly parents. The problems faced by service partners, which lie in the lack of knowledge about maintaining cleanliness during the covid-19 pandemic, and the lack of supporting facilities such as: hand sanitizers, masks, etc. The purpose of holding this service activity is to increase knowledge to the community about the importance of clean living. The implementation method carried out in this activity is through the socialization stage, the preparation stage and the evaluation stage. The result is an increased understanding in the community about the importance of keeping the environment clean, by always washing hands after leaving the house, maintaining distance, not littering, and always wearing masks when doing activities outside the home.
\end{abstract}

Keywords: Counseling, healthy and clean living behavior, covid-19 pandemic

\begin{abstract}
Abstrak
Menjaga kebersihan dan kesehatan lingkungan sejak dini merupakan salah satu faktor terpenting yang harus diperhatikan di dalam kehidupan sehari-hari, terlebih saat ini negara kita bahkan dunia sedang mengalami masa pandemi covid-19, oleh karena itu kesehatan diri dan lingkungan perlu diperhatikan khususnya bagi anak-anak dan orang tua yang lanjut usia. Permasalahan yang dihadapi mitra pengabdian, yaitu terletak pada minimnya pengetahuan mengenai menjaga kebersihan dimasa pandemi covid-19, dan kurangnya fasilitas pendukung seperti: hand sanitizer, masker dll. Tujuan diadakannya kegiatan pengabdian ini untuk meningkatkan pengetahuan kepada masyarakat mengenai mengenai pentingnya hidup bersih. Adapun metode pelaksanaan yang dilakukan dalam kegiatan ini adalah melalui tahap sosialisasi, tahap persiapan dan tahap evaluasi. Hasilnya adanya peningkatan pemahaman di masyarakat mengenai pentingnya menjaga kebersihan lingkungan, dengan selalu mencuci tangan setelah keluar rumah, tetap menjaga jarak, tidak membuang sampah sembarangan, dan selalu menggunakan masker saat beraktivitas di luar rumah.
\end{abstract}

Kata kunci : Penyuluhan, perilaku hidup sehat dan bersih, pandemi covid-19

@2021 Penerbit PS2PM FISIPKUM UNSERA Segala bentuk plagiarisme dan penyalahgunaan hak kekayaan intelektual akibat diterbitkannya artikel pengabdian masyarakat ini sepenuhnya menjadi tanggung jawab penulis

Marthalena, Siska Mardiana, Rethorika Berthanilla, Meningkatkan Kesadaran Orang Tua Dan Anak Melalui Penyuluhan Mengenai Penerapan Protokoler Kesehatan di Masa Pandemi covid - 19 di Paud Nur Qolbu Lingkungan Perumnas Ciracas Kelurahan Ciracas Kecamatan Serang Kota Serang Provinsi Banten 


\section{PENDAHULUAN}

Kegiatan

pengabdian

masyarakat ini dilakukan di Paud Nur

Qolbu yang terletak di Perumnas

Ciracas. PAUD ini terletak di salah satu perumahan nasional di kecamatan Serang Kota Serang, provinsi Banten. PAUD ini memiliki kurang lebih 15 peserta didik yang berasal dari lingkungan sekitar. Lokasi PAUD Nur Qolbu sendiri terletak di Kecamatan Serang, kecamatan Serang sendiri merupakan salah satu dari 6 kecamatan di kota Serang dengan jumlah penduduk kurang lebih 244,05 jiwa, wilayah kecamatan Serang memiliki luas 25,88 $\mathrm{km}$.

Pemilihan lokasi di Paud Nur Qolbu di Perumnas Ciracas Kota Serang berdasarkan hasil observasi yang telah dilakukan sebelumnya bahwa di daerah ini masih terdapat anak-anak yang tidak mengikuti anjuran pemerintah untuk mengikuti protokoler kesehatan saat bermain di luar rumah. Tidak hanya itu saja permasalahan dalam kegiatan belajar juga menjadi persoalan ini sangat di perlukan di tengah pendemic covid19 ini.

Lingkungan Perumnas Ciracas mayoritas masyarakatnya bekerja sebagai pegawai swasta, bahkan sebagian warganya bekerja serabutan. Peserta didik di PAUD Nur Qolbu ini hampir sebagian besar berasal dari keluarga tidak mampu sehingga anak-anak peserta didiknya banyak tidak mendapatkan fasilitas kebersihan selama pandemik covid-19 ini. Hasil obeservasi awal secara umum anak-anak kurang menjaga kebersihan diri dan lingkungan, yaitu tidak menggunakan masker saat bermain di luar rumah, jarang mencuci tangan setelah beraktivitas di luar rumah karena tidak memiliki hand sanitizer. Hal ini terjadi karena minimnya pengetahuan orang tua dan tidak mendapat fasilitas pencegahan pada masa pandemic covid-19.

Marthalena, Siska Mardiana, Rethorika Berthanilla, Meningkatkan Kesadaran Orang Tua Dan Anak Melalui Penyuluhan Mengenai Penerapan Protokoler Kesehatan di Masa Pandemi covid - 19 di Paud Nur Qolbu Lingkungan Perumnas Ciracas Kelurahan Ciracas Kecamatan Serang Kota Serang Provinsi Banten 
Di tengah kondisi pandemi Covid-19 sekarang ini, penerapan perilaku hidup bersih dan sehat (PHBS) oleh setiap warga masyarakat dari anak-anak hingga orang dewasa disebut sebagai cara yang paling efektif dalam mencegah infeksi dan penyebaran Covid-19 (Karo, 2020; Kementerian Kesehatan, 2016; Tabi'in, 2020; Zukmadini, et al, 2020). Dengan cara rajin mencuci tangan dengan air bersih dan sabun, makan makanan yang bergizi seperti buah dan sayur, penggunaan masker saat di luar rumah, serta melakukan aktivitas fisik secara rutin merupakan perilaku yang dapat mencegah infeksi Covid-19. Aktivitas seperti ini tentu mudah dipahami oleh orang dewasa tapi tidak mudah bagi anak-anak. Oleh karena itu penyuluhan untuk selalu menjaga kebersihan diri dan lingkungan kepada anak-anak yang dilakukan secara berkelanjutan penting untuk terus dilakukan. Karena anak-anak termasuk kelompok yang cukup rentan terserang penyakit.

Dengan memperhatikan dan mempertimbangkan kondisi dan situasi disekitar Lingkungan Perumnas Ciracas ini, maka kami memandang perlu diadakannya kegiatan pengabdian ini dengan melibatkan mahasiswa dan warga sekitar Perumnas Ciracas, yaitu dengan melaukan kegiatan penyuluhan mengenai peningkatan pengetahuan pentingnya menjaga kebersihan diri dan lingkungan, dan memberikan fasilitas penujang pencegahan covid-19 kepada warga.

\section{METODE PELAKSANAAN}

Metode yang digunakan adalah Participatory Learning And Action merupakan bentuk baru dari metode pemberdayaan masyarakat yang sebelumnya lebih dikenal dengan "Learning by Doing" atau belajar sambil bekerja (Phuyal, 2008; IIED, 2013). Participatory Learning Action merupakan proses belajar 
secara berkelompok yang dilakukan secara interaktif dalam suatu proses kerja (Appeldkk,2012). Kegiatan PKM berkonsep Participatory Learning and Action ini dilakukan dengan menekankan pada kegiatan ceramah, diskusi, curah pendapat yang dilakukan secara interaktif dengan orang tua dan murid-murid dari PAUD Nur Qolbu dan dilanjutkan dengan aksi atau kegiatan riil yang relevan dengan materi pemberdayaan masyarakat.

Metode yang digunakan dalam pelaksanaan kegiatan pengabdian masyarakat ini adalah dengan metode penyuluhan mengenai pentingnya menjaga kebersihan diri dan lingkungan serta memberikan bantuan berupa penyediaan fasilitas seperti masker (face shield) dan hand sanitizer. Adapun proses kegiatan ini terdiri atas beberapa tahapan, yaitu sosialisasi, persiapan penyuluhan, pelaksanaan penyuluhan serta evaluasi. Dalam proses pelaksanaannya kegiatan pengabdian ini akan dilaksanakan melalui tiga tahap yaitu tahap awal, tahap inti dan tahap akhir. Secara umum tahapan kegiatan pengabdian ini sebagai berikut:

\section{Tahap awal.}

Pada kegiatan pengabdian ini adalah tahap sosialisasi dan perijinan. Pada tahapan ini, kami (tim pengabdian) melakukan observasi dimasyarakat mengenai permasalahan yang ada, kemudian mendiskusikannya dengan kepala sekolah PAUD Nur Qolbu Perumnas Ciracas dikediamannya, yang dihadiri oleh perwaklian orang tua serta meminta ijin bahwa akan diadakan kegiatan tersebut.

\section{Tahap kedua.}

Tahapan persiapan. Pada tahap persiapan ini, kami tim PKM mendiskusikan tentang berbagai kebutuhan alat dan bahan yang dibutuhkan serta merencanakan teknis pelaksanaan kegiatan tersebut, juga berkoordinasi dengan ketua RT

Marthalena, Siska Mardiana, Rethorika Berthanilla, Meningkatkan Kesadaran Orang Tua Dan Anak Melalui Penyuluhan Mengenai Penerapan Protokoler Kesehatan di Masa Pandemi covid - 19 di Paud Nur Qolbu Lingkungan Perumnas Ciracas Kelurahan Ciracas Kecamatan Serang Kota Serang Provinsi Banten 
setempat, yang kemudian dilanjutkan dengan tahap pelaksanaan.

3. Tahap akhir.

Tahap evaluasi yang dilakukan dalam kegiatan ini adalah kegiatan dan keaktifan para peserta yang hadir saat penyuluhan, tingkat pengetahuan mereka dalam memahami materi yang disampaikan dan evaluasi terkait dengan kegiatan ini selanjutnya.

\section{HASIL DAN PEMBAHASAN}

Kegiatan pengabdian dilakukan di PAUD Nur Qolbu yang melibatkan mahasiswa secara keseluruhan dan murid-murid PAUD Nur Qolbu serta beberapa orang tua yang sedang mendampingi anaknya. Adapun kegiatan tersebut sebagai berikut:

a. Tahap awal

Pada tahap awal kegiatan, ada dua agenda utama yang dilakukan yaitu observasi dan survey lapangan. Kegiatan observasi dan survey lapangan dilakukan di minggu pertama, tim kami berkeliling melihat lingkungan sekitar dan mendapati kondisi anak-anak yang sedang bermain di lingkungan sekitar yang tidak menggunakan alat pelindung diri dari covid-19 seperti masker (faceshield), tidak menjaga jarak saat bermain, serta tidak mencuci tangan setelah bermain di luar rumah. Tim juga mendatangi warga dan berbincang, lalu didapat informasi banyak orang tua yang masih minim terkait dengan informasi pencegahan covid-19.

b. Tahap Persiapan

Pada tahap ini, dilakukan pada minggu kedua bulan agustus, tim kami mempersiapkan alat dan bahan yang dibutuhkan. Untuk kegiatan penyuluhan peningkatan pengetahuan terkait dengan covid-19, tim menyediakan total 20 face shield dan alat pembersih cuci tangan (handsanitizer) sebanyak 25 buah. Faceshield dan handsanitizer dibagikan kepada seluruh muridmurid PAUD Nur Qolbu setelah kegiatan penyuluhan berlangsung.

Marthalena, Siska Mardiana, Rethorika Berthanilla, Meningkatkan Kesadaran Orang Tua Dan Anak Melalui Penyuluhan Mengenai Penerapan Protokoler Kesehatan di Masa Pandemi covid - 19 di Paud Nur Qolbu Lingkungan Perumnas Ciracas Kelurahan Ciracas Kecamatan Serang Kota Serang Provinsi Banten 
Teknis penggunaan alat-alat tersebut juga disampaikan saat pembagian kepada seluruh murid-murid. Menggunakan hand sanitizer merupakan salah satu tindakan yang bisa dilakukan untuk mencegah penularan virus. Sebab, hand sanitizer terbukti secara klinis mampu mengurangi bakteri, kuman, dan virus yang menempel pada tangan manusia. kebutuhan akan benda satu ini tampaknya semakin meningkat di tengah pandemi virus corona covid-19 yang merebak ke seluruh dunia.

c. Tahap Pelaksanaan

Tahap pelaksanaan adalah kegiatan penyuluhan dan kegiatan penyerahan kepada mitra dalam kegiatan pengabdian masyarakat ini dilaksanakan pada minggu ketiga bulan agustus. Pelaksanakan diawali dengan kegiatan penyuluhan terkait dengan menerapkan protokoler kesehatan bagi anak-anak serta pentingnya pola hidup bersih di masa pandemic ini, dan dilanjutan dengan penyerahan 20 faceshield yang dibagikan kepada seluruh muridmurid PAUD Nur Qolbu di lingkungan Perumnas Ciracas, dan 20 botol hansanitizer, dan pembagian bingkisan berupa makanan sehat (susu, roti dan buah-buahan). Semua peserta begitu antusias selama mengikuti kegiatan penyuluhan ini, nampak dari beberapa murid-murid yang begitu semangat selama mengikuti kegiatan ini.

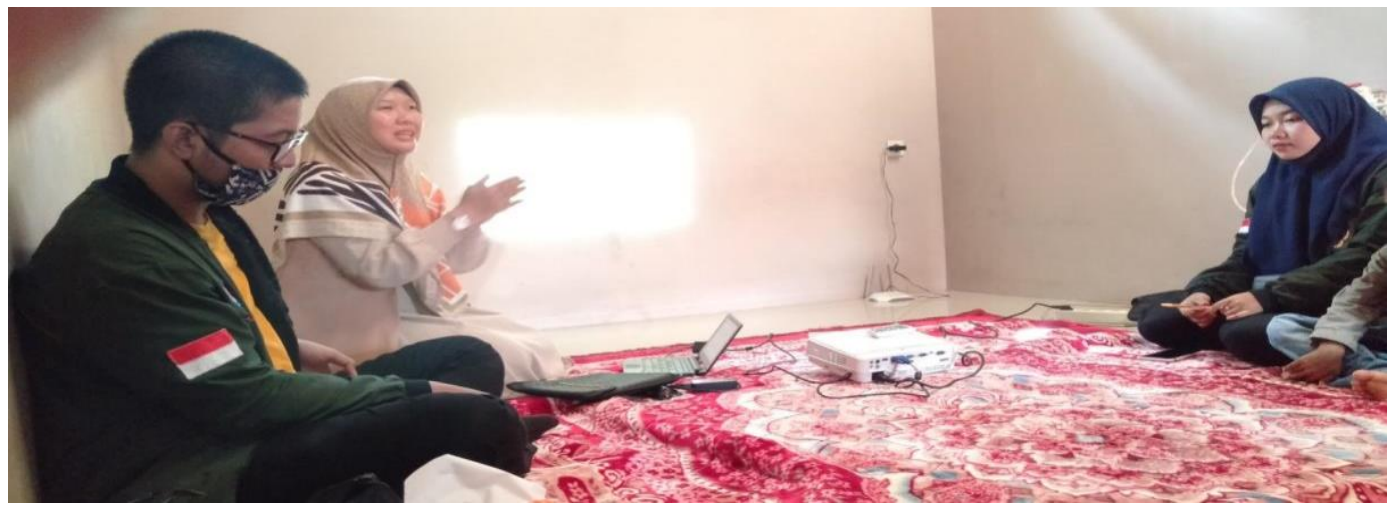

Gambar. 1

Kegiatan penyuluhan berupa materi tentang penerapan protokoler kesehatan selama pandemi Covid-19

Marthalena, Siska Mardiana, Rethorika Berthanilla, Meningkatkan Kesadaran Orang Tua Dan Anak Melalui Penyuluhan Mengenai Penerapan Protokoler Kesehatan di Masa Pandemi covid - 19 di Paud Nur Qolbu Lingkungan Perumnas Ciracas Kelurahan Ciracas Kecamatan Serang Kota Serang Provinsi Banten 


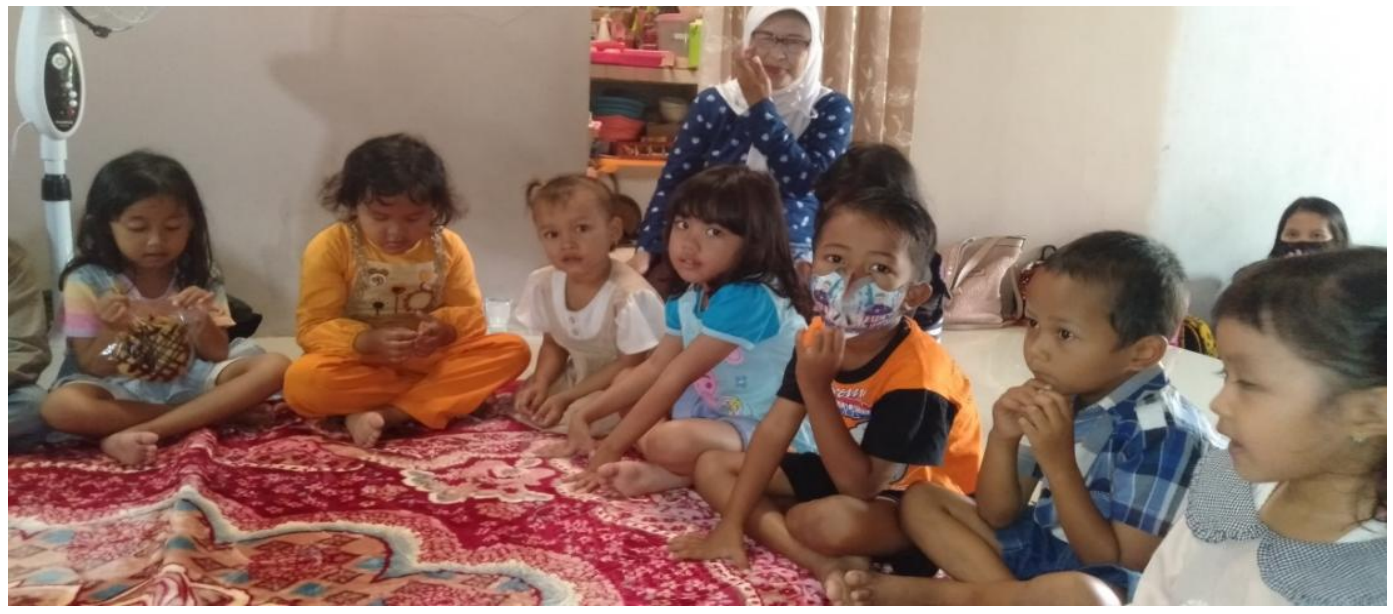

Gambar. 2

Murid-murid PAUD Nur Qolbu nampak antusias

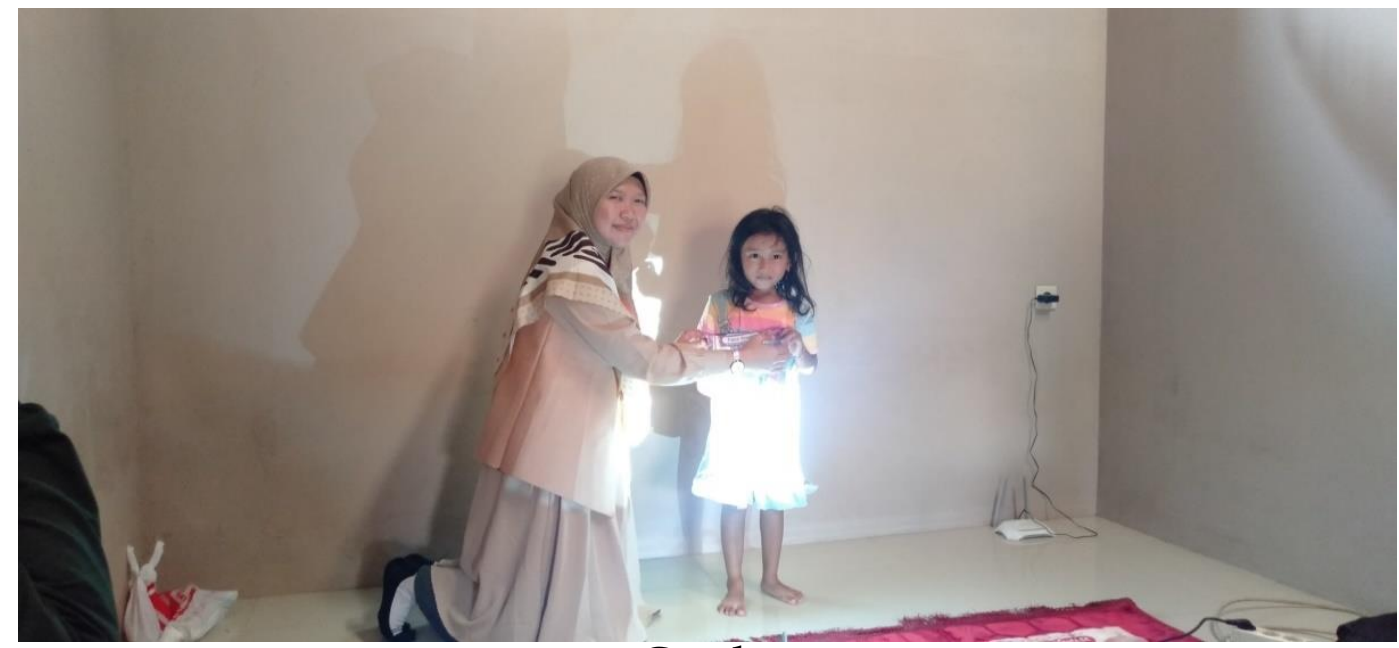

Gambar. 3

Kegiatan penyerahan handsanitizer

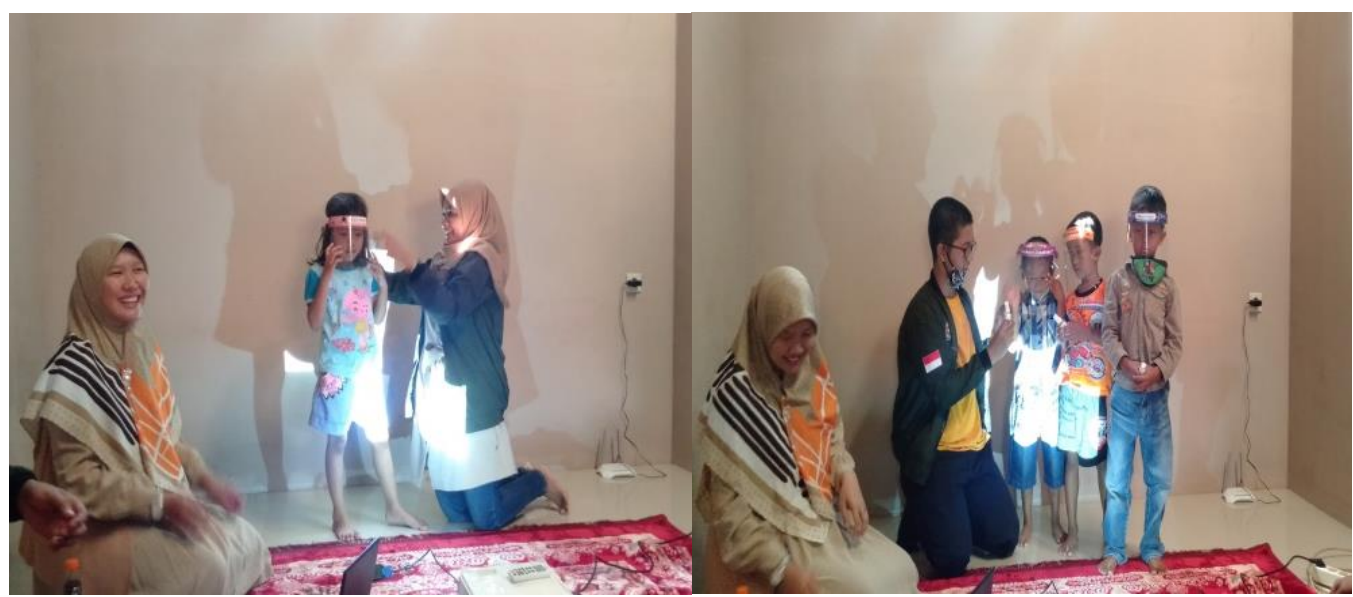

Gambar. 4

Kegiatan penyerahan faceshield dan cara menggunakannya

Marthalena, Siska Mardiana, Rethorika Berthanilla, Meningkatkan Kesadaran Orang Tua Dan Anak Melalui Penyuluhan Mengenai Penerapan Protokoler Kesehatan di Masa Pandemi covid - 19 di Paud Nur Qolbu Lingkungan Perumnas Ciracas Kelurahan Ciracas Kecamatan Serang Kota Serang Provinsi Banten 
Tahap terakir dari keseluruhan kegiatan pengabdian ini adalah melakukan evaluasi kegiatan. Tim melihat semua peserta begitu sangat antusias dan sangat mendukung kegiatan pengabdian ini dimulai dari beberapa partipasi masyarakat dalam kegiatan penyuluhan dan penyerahan beberapa alat pendukung pola hidup bersih dan sehat selama covid-19, hasil dari wawancara tentang kegiatan ini banyak orang tua dan kepala sekolah serta guru-guru PAUD merasa cukup puas, mereka jadi lebih mengetahui kebersihan lingkungan dan pentingnya kesehatan apalagi dimasa pandemik corona-19 seperti sekarang ini.

Tabel 1

Jadwal Kegiatan

\begin{tabular}{|l|l|l|l|l|}
\hline No & \multicolumn{2}{|c|}{ Jenis Kegiatan } & \multicolumn{3}{c|}{ Minggu } \\
\cline { 3 - 5 } & \multicolumn{1}{|c|}{$\begin{array}{l}\text { Tahap Sortama } \\
\text { perijinan }\end{array}$} & Kedua & Ketiga \\
\hline 2 & Tahap persiapan dan & & & \\
\hline 3 & Tahap pelaksanaan & & & \\
\hline 4 & Tahap Evaluasi & & & \\
\hline
\end{tabular}

\section{REFERENSI}

Green, L., dan Kreuter, M. W. (1991).

Health Promotion Planning, An

Educational and Environmental

Approach. California: Mayfield Publishing Co

Karo, M. B. (2020). Perilaku Hidup Bersih dan Sehat (PHBS) Strategi

Pencegahan Penyebaran Virus
Covid 19. Prosiding Seminar Nasional Hardiknas, 1-4

Kementerian Kesehatan. (2016). PHBS. http:// promkes.kemkes.go.id/phbs

Primadi, O. (2017). Sosialisasi Gerakan Masyarakat Hidup Sehat (Germas) dalam Temu Blogger Jawa Barat. http://sehatnegeriku.kemkes

Marthalena, Siska Mardiana, Rethorika Berthanilla, Meningkatkan Kesadaran Orang Tua Dan Anak Melalui Penyuluhan Mengenai Penerapan Protokoler Kesehatan di Masa Pandemi covid - 19 di Paud Nur Qolbu Lingkungan Perumnas Ciracas Kelurahan Ciracas Kecamatan Serang Kota Serang Provinsi Banten 
go.id/wp-

content/uploads/2017/04/Sosiali

sasi-GERMAS-Temu-Blogger-

Jawa-barat-2017. Pp

Tabi'in, A. (2020). Perilaku Hidup

Bersih dan Sehat (PHBS) pada

Anak Usia Dini sebagai Upaya

Pencegahan Covid 19. JEA

(Jurnal Edukasi AUD), 6(1), 58-

73

Marthalena, Siska Mardiana, Rethorika Berthanilla, Meningkatkan Kesadaran Orang Tua Dan Anak Melalui Penyuluhan Mengenai Penerapan Protokoler Kesehatan di Masa Pandemi covid - 19 di Paud Nur Qolbu Lingkungan Perumnas Ciracas Kelurahan Ciracas Kecamatan Serang Kota Serang Provinsi Banten 